\title{
Identification of Pathogenic Leptospira spp. Carrier Goats Using Polymerase Chain Reaction (PCR)
}

\author{
Priti D. Vihol ${ }^{1 *}$, Jatin H. Patel ${ }^{2}$, Jignesh M. Patel ${ }^{1}$, Vijendra S. Dabas ${ }^{3}$, \\ Irshadullakhan H. Kalyani ${ }^{4}$, Chandrakant F. Chaudhari ${ }^{5}$ and Ashish C. Patel ${ }^{6}$ \\ ${ }^{1}$ Department of Veterinary Pathology, ${ }^{2}$ Department of Veterinary Pharmacology and Toxicology, \\ ${ }^{3}$ Department of Surgery and Radiology, ${ }^{4}$ Department of Veterinary Microbiology, \\ ${ }^{5}$ Department of Animal Reproduction Gynecology and Obstetrics, College of Veterinary \\ Sciences and Animal Husbandry, Navsari Agricultural University, \\ Eru cross road, Navsari-396 450, Gujarat, India \\ ${ }^{6}$ Department of Animal Genetics and Breeding, College of Veterinary Sciences and A.H. Anand \\ Agricultural University, Anand- 388001, Gujarat, India \\ *Corresponding author
}

A B S T R A C T

Leptospirosis, an important zoonotic disease with worldwide distribution, is emerging as public health problem in south Gujarat, India where it is endemic. In infected animals, persistent colonization of leptospires in renal tubules is not uncommon and hence chronically infected hosts shed leptospires in urine and

Keywords

Carrier, DNA, PCR, MAT,

Leptospirosis.

Article Info

Accepted:

17 October 2017

Available Online:

10 December 2017 contaminate the environment. A study was undertaken to identify leptospiral carrier goats in south Gujarat using urine polymerase chain reaction. A total of 292 urine and sera samples each were collected randomly from goats reared in different villages of south Gujarat region and studied using polymerase chain reaction (PCR) and microscopic agglutination test (MAT), respectively. In MAT, seroreactivity was noted in $61(20.89 \%)$ goats while leptospiral DNA was detected in $42(14.38 \%)$ goats using PCR. There was low concordance between two tests. To the best of author's knowledge, it is the first study indicating use of PCR in detection of carrier goats from south Gujarat, India. Present findings indicate existence of carrier status of leptospirosis among goats in this area. In conclusion, leptospiral DNA was detected from urine of goats using PCR hence use of PCR may be considered as a valuable tool for identification of carrier goats. Present results also necessitate effective control measures in south Gujarat.

\section{Introduction}

Leptospirosis is a zoonotic disease of global significance (Bharti et al., 2003). The causative organism is pathogenic Leptospira spp. chronically infected mammalian hosts harbor pathogenic Leptospira species in renal tubules and excrete them in urine and hence contaminate the environment. These leptospires survive under suitable moist 
conditions. Leptospiral infection in goats is common in several countries including India. Goats also act as carrier of leptospirosis. Severe infection is common in young animals and is frequently associated to incidental serovars. In contrast, subclinical infection is mainly characterized by reproductive problems, such as infertility, abortion, occurrence of stillbirths and weak kids (Lilenbaum and Martin, 2014). Laboratory tests are essential to accurately diagnose leptospirosis in small ruminants as it usually occurs without apparent clinical signs and typical lesions. Various methods like serology (MAT), dark-field microscopy (DFM), microbial culture, immune based and molecular tools (PCR, Real time PCR) are used to diagnose leptospirosis (Grooms and Bolin, 2005). MAT, the reference serological indirect test has various merits and demerits. So molecular tools have become popular among researchers or laboratories as these are considered to be the most precise and quick diagnostic methods. More recently, PCR become important in laboratories as routine diagnostic tool for diagnosis of leptospirosis in different species of animals (Okata et al., 2012) because it presents high sensitivity and specificity and may detect upto ten leptospires per milliliter of urine (Lilenbaum and Martin, 2014). It is also recommended method for detection of leptospires in urine of carrier animals (Lilenbaum et al., 2009).

In India, there has been an upsurge of the disease in certain states like Tamil Nadu, Kerala, Maharashtra including Gujarat (Himani et al., 2013; Sharma et al., 2014). Leptospirosis is endemic in south Gujarat and is emerging as an important public health problem. Many reports demonstrated occurrence of leptospiral antibodies in goats, sheep, cattle, buffaloes, dogs and humans from the south Gujarat, India using MAT (Savalia and Pal, 2008; Patel et al., 2014; Panwala and Mulla, 2016; Vihol et al., 2016;
Vihol et al., 2017). The climatic condition of south Gujarat favors growth of leptospires.

It has been reported that effective control of leptospirosis in animals involves measures such as identification and treatment of the carriers and other sources of infection, immunization of animals and quarantine of infected animals (Subharat et al., 2011). So the present study was planned to identify carrier goats using PCR.

\section{Materials and Methods}

A total of 292 urine and sera samples each were collected on random basis from apparently healthy and clinically ailing unvaccinated goats of either sex reared in various villages of Valsad, Navsari, Vapi and Surat districts of South Gujarat region where leptospirosis is endemic. These samples were collected on the same visit from goats belonging to individual households, Panjarapol, slaughter house and cases presented at Teaching Veterinary Clinical Complex (TVCC), College of Veterinary Science and Animal Husbandry, Navsari.

\section{Collection of sera samples and MAT}

For sera samples five ml blood was collected by jugular venipuncture in serum vaccutainers from each goat. Samples were brought to the Pathology Laboratory, centrifuged at $1800 \times \mathrm{g}$ for $10 \mathrm{~min}$. to harvest clear sera and stored at $-20^{\circ} \mathrm{C}$ until further use. Paired serum samples were not collected in this study since each animal was sampled only once.

All the sera were tested for antibodies against live antigens of Leptospira sp. serovars Pyrogenes, Australis, Bankinang, Grippotyphosa, Patoc1, Pomona, Icterohaemorrhagiae, Hebdomadis, Canicola, Hardjo, Bellum, Bataviae, Tarassovi, Shermani, Kaup, Hurstbridge and Javanica by 
Microscopic Agglutination Test at Leptospira Reference Laboratory, Government Medical College, Surat using standard procedure (Vijayachari et al., 2001) and/or National Institute of Veterinary Epidemiology and Disease Informatics (NIVEDI), Indian Council of Agricultural Research, Hebbal, Bengaluru using standard procedure (WHO, 2013). The samples were considered reactive with $50 \%$ or more agglutination of leptospires at titers of 40 or more to any of the serovars observed.

\section{Collection of urine samples and PCR}

Midstream urine samples $(30-50 \mathrm{ml})$ were collected in sterile plastic containers after cleaning the vulva or preputial opening. In slaughter animals, urine samples were collected directly from urinary bladder. All the urine samples were placed in ice container and transported to laboratory as soon as possible.

\section{Sample preparation for PCR}

In laboratory urine samples were immediately filtered using 0.45 micrometer pore size filters (Pall Life Science) in sterile $50 \mathrm{ml}$ conical centrifuge tubes. The filtrate was centrifuged at $7800 \mathrm{rpm}$ for 20 minutes at $4^{0} \mathrm{C}$ in a refrigerated centrifuge. After discarding the supernatant, pellet was vortex and transferred to sterile $1.5 \mathrm{ml}$ microcentrifuge tube and resuspended in phosphate-buffered saline $(\mathrm{pH}$ $7.2)$.

Genomic DNA isolation from urine samples

The resuspended pellets were used for DNA extraction using the method described by Ambily et al., (2012) with minor modifications. Briefly, resuspended pellet samples were centrifuged at $14000 \mathrm{rpm}$ for 15 minutes at $4^{0} \mathrm{C}$. The supernatant was discarded and 1ml PBS $(7.2 \mathrm{pH})$ was added to the pellet and centrifuged at $14000 \mathrm{rpm}$ for 10 minutes at $4^{0} \mathrm{C}$. This step was repeated twice, supernatant was discarded and $0.5 \mathrm{ml}$ nuclease free water (Qiagen) was added and centrifuged at $14000 \mathrm{rpm}$ for 10 minutes at $4^{0} \mathrm{C}$ and this step was again repeated. After discarding supernatant $0.1 \mathrm{ml}$ nuclease free water was added to the pellet and vortexed. The tube was placed in boiling water bath for 15 minutes and immediately snap chilled for 20 minutes. After vortexing, samples were stored at $-20^{\circ} \mathrm{C}$ until further analysis. Quality and purity of DNA was checked by submarine agarose gel electrophoresis using 0.8 per cent agarose in 1X TAE (PH 8.0) buffer (Sambrook and Russel, 2001). Ethidium bromide was added @ $0.5 \mu \mathrm{g} / \mathrm{ml}$. The wells were charged with $4 \mu 1$ of DNA preparations mixed with $1 \mu 1$ of $6 \mathrm{X}$ gel loading buffer dye. Electrophoresis was carried out at $5 \mathrm{~V} / \mathrm{cm}$ for $20 \mathrm{~min}$ at room temperature and then the DNA was visualized under UV trans illuminator.

\section{Oligonucleotides primers for PCR}

In the study, earlier reported sets of primers were used to detect leptospiral DNA. PCR was performed using one set of conventional primers i.e. G1/G2 (Gravekamp et al., 1993) and positive samples were retested using the other primer set LipL32 with target amplification on conserved region of major outer membrane protein gene LipL32 (Cheema et al., 2007).

Primers G1 (forward) and G2 (reverse) had sequences 5'CTGAATCGCTGTATAAAAG T3' and 5'GGAAAACAAATGGTCGGAAG 3', respectively. The primer set LipL32 had sequences 'GTCGACATGAAAAAACTTTC GATTTTG3' and 'CTGCAGTTACTTAGTC GCGTCAGAAGC3', respectively, as forward and reverse primers. 


\section{PCR assay}

The PCR was conducted in a final volume of $25 \mu \mathrm{l}$ mixture containing DNase -7.5 $\mu \mathrm{l}$ RNase-free water, $12.5 \mu \mathrm{l}$ Taq PCR master Mix (having 2.5 units Taq DNA Polymerase, 1X PCR Buffer containing1.5 mM $\mathrm{MgCl}_{2}$ and $200 \mu \mathrm{M}$ each dNTPs- M/S:Cat. No. 201443, QIAGEN, Germany), $1.0 \mu \mathrm{l}(20$ pmoles/ $\mu \mathrm{l})$ forward primer, $1.0 \mu \mathrm{l}(20 \mathrm{pmoles} / \mu \mathrm{l})$ reverse primer $(20$ pmoles/ $\mu \mathrm{l})$ and $3.0 \mu \mathrm{l}$ template DNA. The PCR assay was performed as described previously with minor modification (Cheema et al., 2007) in thermal cycler (M/S: BIORAD). Briefly, initial denaturation at $95^{\circ} \mathrm{C}$ for $4 \mathrm{~min}$ followed by 35 cycles of denaturation at $95^{\circ} \mathrm{C}$ for $1 \mathrm{~min}$, annealing at $53^{\circ} \mathrm{C}$ for $1 \mathrm{~min}$, extension at $72^{\circ} \mathrm{C}$ for $1 \mathrm{~min}$ and final extension at $72^{\circ} \mathrm{C}$ for $10 \mathrm{~min}$.

The PCR protocol designed for both $\mathrm{G} 1 / \mathrm{G} 2$ and LipL32 primers were same. The targeted PCR amplification product was checked by electrophoresis. For electrophoresis of PCR product, $4.0 \mu \mathrm{l}$ of PCR product was mixed with $1.0 \mu \mathrm{l}$ of $6 \mathrm{X}$ gel loading buffer and electrophoresed along with 100bp DNA molecular weight marker (Gelipilot ${ }^{\circledR}$, Cat. No. 239035 Qiagen, Germany) on 2.0\% agarose gel containing ethidium bromide (at the rate of $0.5 \mu \mathrm{g} / \mathrm{ml}$ ) at constant $80 \mathrm{~V}$ for $30 \mathrm{~min}$ in $1 \mathrm{X}$ TAE buffer. The amplified product was visualized as a single compact band of expected size under UV light and documented by gel documentation system (Syn Gene, Gene Genius BioImaging System, UK).

For each PCR run, positive and negative control samples were also used. Genomic DNA extracted from culture of $L$. interrogans Serogroup Icterohaemorrhagiae Serovar Icterohaemorrhagiae strain RGA was used as positive control while nuclease free water was added in place of gDNA in negative control.

\section{Statistical analysis}

For statistical analysis, Fisher's exact test was used to assess the response between two categorical variables MAT and PCR. The level of significance was set at $5 \%(\mathrm{P}<0.05)$. Kappa test was also used to evaluate concordance between two tests.

\section{Results and Discussion}

In the study, results of PCR are evaluated and studied including MAT seropositive and seronegative goats for better understating of status of animals.

In present study, out of 292 urine and sera samples tested by PCR and MAT, 42 (14.38 $\%)$ and $61(20.89 \%)$ goats tested positive, respectively using these diagnostic tests. Details of obtained PCR and MAT results are presented in Table 1. For MAT and PCR both the tests, only $18(6.16 \%)$ goats were positive. In a total 61 seroreactive goats tested using MAT, only $18(6.16 \%)$ were positive in PCR, while in $43(14.72 \%)$ goats were negative for leptospiral DNA in urine. However, in $24(8.22 \%)$ seronegative goats, leptospiral DNA was detected in urine samples.

Seroreactivity for antileptospiral antibodies in unvaccinated goats in the present study indicates present or past exposure to leptospires and supported the endemic status of leptospirosis among these animals in this region (Oza et al., 1998, Savalia and Pal, 2008, Vihol et al., 2017). South Gujarat is a tropical region with high humidity, alkaline soil, water logging and high rainfall which is ideal for survival and propagation of leptospires. Suitability of the environment for survival of leptospires appears to be an imperative factor in maintaining the infection among animals or humans (Haji Hajikolaei et al., 2006). 
In urine samples, PCR was able to detect presence of leptospiral DNA using G1/G2 primers. All the positive samples were retested by PCR using another set of primers i.e. LipL32 and in all the tested samples leptospiral DNA was detected. PCR amplification products of expected size i.e. $285 \mathrm{bp}$ and $756 \mathrm{bp}$, respectively were obtained with G1/G2 and LipL32 primers specific for genes of pathogenic Leptospira (Figure 1) in all positive samples.

In present study, for diagnostic purpose, G1/G2 specific PCR was used as standard PCR and the positive samples were retested using LipL32 specific PCR. Similarly Cheema et al., (2007) reported diagnostic use of these primers for detection of leptospiral DNA in cattle, buffaloes and experimentally infected guinea pigs and calves.

It has been reported that primers G1/G2 detects pathogenic leptospires except Leptospira kirschneri (Gravekamp et al., 1995). Use of LipL32 gene specific primers was aimed because these primers target a known gene sequence reported to be conserved in all the pathogenic Leptospira species only (Cheema et al., 2007) and hence it distinguishes between pathogenic and nonpathogenic Leptospira species, as well as other microorganisms too (Azizi et al., 2012, Tansuphasiri et al., 2006). In past, many workers have successfully used G1/G2 (Gravekamp et al., 1993, Oliveira et al., 2003, Cheema et al., 2007, Shivaraj et al., 2009, Mineiro et al., 2011, Dehkordi et al., 2011) and LipL32 primers (Bomfim et al., 2008, Meenambigai et al., 2011, Azizi et al., 2012) for diagnostic purpose. Nevertheless, other primers (LipL21, LipL32, LipL41, 16SrRNA) have also been used by various workers (Van
Eys et al., 1989, Lucchesi et al., 2004, Lilenbaum et al., 2009, Shivraj et al., 2009, Ambily et al., 2012) for the detection of leptospiral DNA in various biological materials.

Leptospirosis, zoonotic disease caused by pathogenic spirochetes of the genus Leptospira spp. is transmitted primarily via exposure to contaminated soil or water and contact with urine of infected animals (Adler and de la Pena Moctezuma, 2010). It is reported that once infected, the affected animal excrete organism in urine over a period of time. The disease has worldwide distribution including various states of India. It is prevalent in Valsad, Navsari, Surat and Tapi districts of south Gujarat region since 1994 (Clerke et al., 2002).

The disease is reported in goats, sheep, cattle, buffaloes, dogs and humans (Patel et al., 2006; Savalia and Pal, 2008; Patel et al., 2014; Panwala and Mulla, 2016; Vihol et al., 2016; Vihol et al., 2017) in this region. Based on studies conducted in Gujarat, it was highlighted that agro-climatic conditions like heavy rainfall, clay soil and high water table of south Gujarat favor endemicity for leptospirosis. It is noteworthy to state that in all these seroepidemiological studies, MAT was used for detection of antileptospiral antibodies as indirect test.

Control of disease leptospirosis in small ruminants involves measures like diagnosis and treatment of infection, identification of carriers or source of infection or reservoirs, quarantine of affected animals, vaccination (Lucheis et al., 2004; Lilenbaum and Martins, 2014). 
Table.1 Results of PCR and MAT in goats

\begin{tabular}{|c|c|c|c|c|}
\hline Tests & MAT (Positive) & MAT (Negative) & Total & P value \\
\hline PCR (Positive) & $18(6.16 \%)$ & $24(8.22 \%)$ & $\mathbf{4 2}(\mathbf{1 4 . 3 8} \%)$ & \multirow{2}{*}{$0.0004 *$} \\
\cline { 1 - 4 } PCR (Negative) & $43(14.72 \%)$ & $207(70.89 \%)$ & $\mathbf{2 5 0}(\mathbf{8 5 . 6 1} \%)$ & \\
\hline Total & $\mathbf{6 1}(\mathbf{2 0 . 8 9} \%)$ & $\mathbf{2 3 1} \mathbf{( 7 9 . 1 1 \% )}$ & $\mathbf{2 9 2}$ & \\
\hline
\end{tabular}

Note: ** - Significant at $\mathrm{P}<0.05$

Fig.1 Agarose gel electrophoresis pattern of PCR products of template DNA amplified with primer pairs G1/G2 (approximately 285bp) and LipL32 (approximately 756bp)

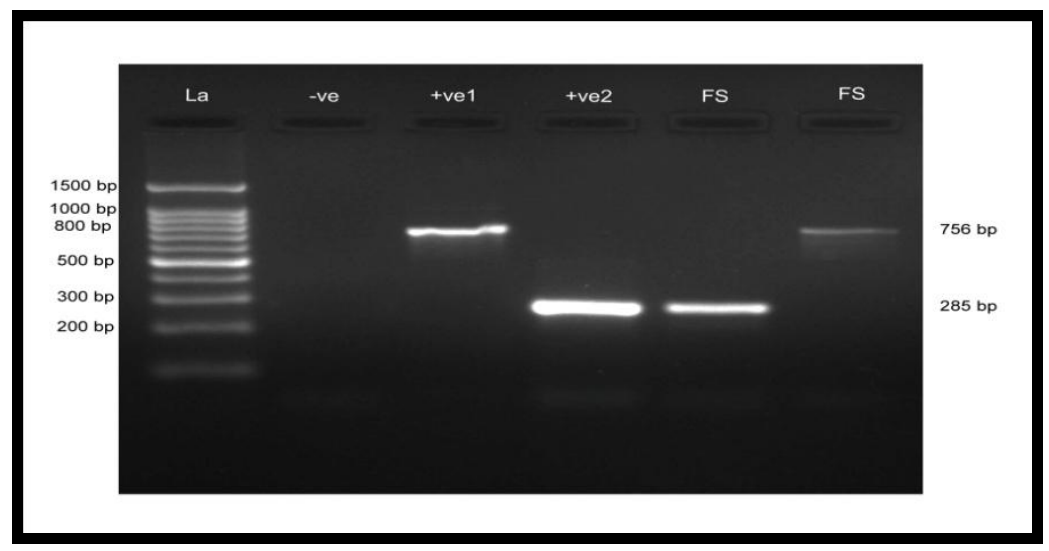

Note:

La: DNA molecular weight ladder 100bp+

-ve: Negative Control

+ve 1: Positive Control (Leptospira interrogans) using primer pair LipL32

+ve 2: Positive Control (Leptospira interrogans) using primer pair G1/G2

Hence for effective and successful control of leptospirosis, identification of carrier animals on individual basis is required as they contaminate the environment and spread leptospires to other animals (Bomfim et al., 2008). It is reported that, although serology is useful for herd diagnosis, it is not adequate for detection of individual carriers (Gamage et al., 2012; Hamond et al., 2014; Otaka et al., 2012) since seronegative animals also can shed leptospires. Therefore, an identification of carrier animals by direct tests like PCR or culture is more useful (Bomfim et al., 2008; Gamage et al., 2012). Since direct detection of antigen by culture of organism is laborious, slow and time consuming other approaches are now preferred by researchers like detection of DNA of Leptospira organism from biological samples using molecular tools like PCR. Despite the fact that, microscopic agglutination test, the reference serological indirect test is recommended by World Organization of Animal Health for definitive diagnosis of leptospirosis in different species of animals (WHO, 2013) with the major advantage that it has serogroup specificity and detects both $\mathrm{IgG}$ and $\operatorname{IgM}$, it has some disadvantages like requirement of live antigens, maintenance of culture of Leptospira organism and repeated subculture of large numbers of strains in the laboratory which poses risk of health hazards for laboratory workers. Besides, MAT provides information on prevalent serovars/serogroups in the screened area; it fails to detect type of immunoglobulin and is preferred with emphasis on titre for sero-epidemiological, screening studies or diagnosis of 
leptospirosis. It has also been noted that many animals carry the organism in kidneys without detectable titre of MAT (Okata et al., 2012). Yet the correlation of serology with presence of bacteria in kidney of organism is not evident, so in small ruminants like goat in which chronic infection with intermittent leptospiruria and maintaining the infection in flock as carrier is common, direct detection of organism is necessary for identification of such animals.

Presently, PCR was used for detection of leptospiral DNA from urine samples of goats and supported the results of the previous reports where in using PCR leptospiral DNA was detected in variety of clinical samples (Gravekamp et al., 1993, Lilenbaum et al., 2008). Presence of leptospiral DNA in urine indicates shedding of leptospires by infected animals. This supports the findings of Faine (1982), who reported that the organism have tendency to lodge in kidneys when the acute phase of the disease is over. Moreover, it is often stated that Leptospira are only present in urine from around the $7^{\text {th }}$ day of the disease (Yang et al., 2001). Sensitivity of the test is also good with detection limit $10^{2}$ leptospires per mililitre of sample (Stoddard et al., 2009). The present results of urinary PCR indicated leptospiral DNA in tested goats which confirms carrier status of disease among these animals in south Gujarat. In addition, the future use of PCR to detect carrier animals besides its applicability as diagnostic tool may be considered (Bomfim et al., 2008).

In the present study, seroreactivity was found to be statistically significant in relation to PCR results $(\mathrm{P}<0.05)$. This indicates results are independent. Out of 61 seropositive goats, leptospiral DNA was found in urine samples of only 18 goats. Likewise, in PCR, out of 42 goats with leptospiral DNA in urine samples, $24(8.22 \%)$ goats were seronegative in MAT. There is discrepancy in results of MAT and
PCR. The two tests revealed least agreement between themselves $(\mathrm{k}<0.40)$. The role of some PCR inhibitors could not be neglected for low PCR positivity in seropositive animals. It is noteworthy to state that the excretion of leptospires in urine is intermittent. Therefore negative results on PCR may not exclude possibility of the animal being carrier. While DNA of leptospires in seronegative animals indicates that MAT was not able to detect carrier animals due to very low or undetectable titer and supported the earlier findings (Hamond $e t$ al., 2014). Another possibility is that, the animal might have exposed to different serovar which was not included in present MAT panel. It also point out regular periodic testing/screening of animals in this area to identify carriers.

Leptospiral infection in goats is common in several countries and this species can also act as carriers of leptospires (Lilenbaum and Martins, 2014). Pathogenic leptospires live in the proximal renal tubules of reservoir animals and are excreted in urine, hence contaminating surface water. So the environmental contamination results in acquisition of infection by the livestock and wild animals. The domestic animals maintain the disease because of continued exposure to asymptomatic carriers or transmission within herds (Grevemeyer et al., 2017). It is reported that continuous or intermittent excretion of leptospires in urine of carriers plays an important role in transmission of transmission of leptospirosis between animals or humans (Lilenbaum et al., 2009). Hence effective control measures should include identification and treatment of carriers (Faine et al., 1999). PCR is used to diagnose leptospirosis even in first week (acute stage) or during carrier stage (chronic stage) by different sets of primers from blood and urine samples, respectively. The main limitation for urine PCR is that one single negative result at PCR does not exclude 
the possibility that the animal is infected, since shedding of leptospires in urine has been referred as intermittent in livestock (Adler and de la Peña Moctezuma, 2010). Unfortunately, under field conditions, repeated sampling could be difficult and less feasible (Hamond et al., 2014). In the present study, leptospiral DNA was detected in urine by PCR among goats. This reminds us to pay attention to surveillance of leptospirosis in this region.

Urinary PCR should be considered as potential tool for identification of carrier animals. Primer set LipL32 and/or G1/G2 may be used in urinary PCR for detection of pathogenic Leptospira spp.

\section{Acknowledgements}

Authors are thankful to the Dean and Principle and Associate Professor and Head, Department of Veterinary Pathology, Vanbandhu College of Veterinary Sciences \& A.H., Navsari Agricultural University, Eru cross road, Navsari, Gujarat, India for providing the necessary facilities to carry out this work. Authors are also thankful to Dr. Sumaiya Mulla, Professor and Head and Incharge Leptospirosis Reference Laboratory at Government Medical College, Surat and Dr. A. R. Rehman, Director, National Institute of Veterinary Epidemiology and Disease Informatics (NIVEDI), Indian Council of Agricultural Research, Hebbal, Bengaluru for technical support.

\section{References}

Adler, B. and de la Pena Moctezuma A. 2010. Leptospira and leptospirosis. Vet. Microbiol. 140(3-4): 287-296.

Ambily, R., Mini, M., Siju, J. and Krishna S. V. 2012. LipL41 gene specific PCR for the detection of pathogenic leptospires in cattle. J. Ind. Vet. Assoc. Kerala. 10(2): 57.
Azizi, S., Tajbakhsh, E., Hajimirzaei, M. R., Varnamkhasti, M. G., Sadeghian, H. and Oryan, A. 2012. Evaluation of "whitespotted kidneys' associated with leptospirosis by polymerase chain reaction based LipL32 gene in slaughtered cows. J. South African Vet. Assoc. 83(1): 1-5.

Bharti, A. R., Nally, J. E., Ricaldi, J. N., Matthias, M. A., Diaz, M. M. and Lovett, M. A. 2003. Leptospirosis: a zoonotic disease of global importance. Lancet Infect. Dis. 3(12): 757-771.

Bomfim, M. R. Q., Barbosa-Stancioli, E. F. and Koury, M. C. 2008. Detection of pathogenic leptospires in urine from naturally infected cattle by nested PCR. Vet. J. 178: 251-256.

Cheema, P. S., Srivastava, S. K., Amutha, R., Singh, S., Singh, H. and Sandey, M. 2007. Detection of pathogenic leptospires in animals by PCR based on lipL21 and lipL 32 genes. Indian J. Exp. Biol. 45: $568-573$.

Clerke, A. M., Leuva, A. C., Joshi, C. and Trivedi, S. V. 2002. Clinical profile of leptospirosis in south Gujarat. J. Post Grad. Med. 48: 117-118.

Dehkordi, J. A., Shahbazkia, H. R. and Ronagh, N. 2011. Evaluation of pathogenic serovars of Leptospira interrogans in dairy cattle herds of Shahrekord by PCR. Iran. J. Microbiol. 3(3): 135-139.

Faine, S. 1982. In: Guidelines for the control of leptospirosis. Geneva WHO, 67.

Faine, S., Adler, B., Bolin, C. and Perolat, P. 1999. Leptospira and leptospirosis. $2^{\text {nd }}$ ed. Med. Sci., Melbourne, Australia.

Gamage, C. D., Koizumi, N., Perera, A. K., Muto, M., Nwafor-Okoli, C., Ranasinghe, S., Kularatne, S. A., Rajapakse, R. P., Kanda, K., Lee, R. B., Obayashi, Y., Ohnishi, M. and Tamashiro, H. 2012. Carrier status of leptospirosis among cattle in Sri Lanka: a zoonotic threat to public health. Transbound. Emerg. Dis. 61(1): 91-96.

Gravekamp, C., Kemp, H.V.D., Franzen, M., Carrington, D., Schoone, G.J., Van Eys, 
G.J.J.M., Everard, C.O.R., Hartskeerl, R.A. and Terpstra, W.J. 1993. Detection of seven species of pathogenic leptospires by PCR using two sets of primers. $J$. General Microbiol. 139: 1691-1700.

Grevemeyer, B., Vandenplas, M., Beigel, B., Cho, E., Willingham, A. L. and Verma, A. 2017. Detection of leptospiral DNA in the Urine of Donkeys on the Caribbean Island of Saint Kitts. Vet. Sci. 4(2).

Grooms, D. L. and Bolin, C. A. 2005. Diagnosis of fetal loss caused by bovine viral diarrhea virus and Leptospira spp. Vet. Clin. North Am. Food. Anim. Pract. 21: 463-472.

Haji Hajikolaei, M. R., Ghorbanpour, M. and Abdollapour, G. R. 2006. Seroprevalence of leptospiral infection in buffalo (Bubalus bubalis). Bull. Vet. Inst. Pulawy. 50: 341-344.

Hamond, C., Martins, G., Lilenbaum, W. and Medeiros, M. A. 2014. PCR detection of leptospiral carriers among seronegative horses. Vet. Rec. 171:105-106.

Himani, D., Kumar Suman, M. and Mane, B. G. 2013. Epidemiology of leptospirosis: an Indian perspective. J. Foodborne Zoonotic Dis. 1(1): 6-13.

Lilenbaum, W. and Martin, G. 2014. Leptospirosis in cattle: a challenging scenario for the understanding of the epidemiology. Transbound. Emerg. Dis. 61: 63-68.

Lilenbaum, W., Varges, R., Branda, F.Z., Cortez, A., De souza, S.O., Branda, P.E., Richtzenhain, L.J., and Vasconcellos, S.A., 2008. Detection of Leptospira spp. in semen and vaginal fluids of goats and sheep by polymerase chain reaction. Theriogenol., 69: 837-842.

Lilenbaum, W., Varges, R., Ristow, P., Cortez, A., De souza, S. O., Richtzenhain, L. J. and Vasconcellos, S. A. 2009. Identification of Leptospira spp. carriers among seroreactive goats and sheep by polymerase chain reaction. Res. Vet. Sci. 87:16-19.

Lucchesi, P. M. A., Arroyo, G. H. Etcheverría, A. I., Parma, A. E. and Seijo, A. C. 2004.
Recommendations for the detection of Leptospira in urine by PCR. Revista da Sociedade Brasileira de Medicina Tropical. 37(2): 131-134.

Meenambigai, T. V., Ravikumar, G., Srithar, A., Balakrishnan, G., Saranya, C. and Muralimanohar, B. 2011. Simultaneous detection of LipL32 and LipL21 genes of pathogenic Leptospira from serum samples of bovines by multiplex PCR. Vet. Sci. Development. 1(1): e15.

Mineiro, A. L. B. B., Vieira, R. J., Costa, E. A., Santos, R. L., Concalves, L. M. F. and Carvalho, S. M. 2011. Serology polymerase chain reaction and histopathology for leptospirosis in sample collected at slaughter house from dairy cows of Parnaiba region, State of Piaul, Brazil. Pesquisa Veterinaria Brasileira. 31: 859-866.

Oliveira, R. C., Cebellero, O. L., Vago, A. R., Hartskeerl, R. A., Romnah, A. J., Pena, S. D., Simpson, A. J. and Kaury, M. C. 2003. Low-stringency single specific primer PCR for identification of Leptospira. J. Med. Microbiol. 52: 127135.

Otaka, D. Y., Martins, G., Hamond, C., Penna, B., Medeiros, M. A. and Lilenbaum, W. 2012. Serology and PCR for bovine leptospirosis: herd and individual approaches. Vet. Rec. 170:338.

Oza, V. V., Sthanki, D. G., Desai, P. U. and Bhavsar, B. K. 1998. Seroprevalence of Leptospira in domestic animals in relation to leptospirosis in humans in Valsad district of Gujarat state. Veterinarian. 22: 15-17.

Panwala, Tanvi and Mulla, Summaiya. 2016. To identify the prevalence Leptospira serogroups in the cases from southern gujarat region. National J. Lab. Med. 5(2): 34-38

Patel, B. K., Gandhi, S. J. and Desai, D. C. 2006. Clinico-epidemiological aspects of leptospirosis in south Gujarat. Indian $J$. Med. Microbiol. 24(4). 322-326.

Patel, J. M., Vihol, Priti, D., Prasad, M. C., Kalyani, I. H., Raval, J. K., Patel, K. M., 
ThirumaleshSushma, R. A. and Balamurugan, V. 2014. Sero epidemiological pattern of leptospirosis in bovine of South Gujarat, India. Vet. World. 7(11): 999-1003.

Sambrook, J. and Russel, D.W. 2001. Molecular Cloning: A Laboratory Manual, $3^{\text {rd }}$ ed., Cold Spring Harbor Laboratory, Cold Spring Harbor, NY, PP: 188-192.

Savalia, C. V. and Pal, M. 2008. Studies on the reservoir status of leptospirosis in Gujarat. I. J. Field Vet. 4(1): 7-9.

Sharma, S., Vijayachari, P., Sugunan, A. P., Roy, S. and Kalimuthusamy, N. 2014. Seroprevalence and carrier status for leptospirosis in cattle and goats in Andaman Island, India. J. Vet. Sci. Technol. 5: 205. doi:10.4172/21577579.1000205.

Shivaraj, M. D., Venkatesha,, Rajkumari Sanjukta, K., Sripad, S., Chandranaik, B. M. and Renukaprasad, C. 2009. Leptospirosis in sheep and its diagnosis. Vet. World. 2(7): 263-264.

Stoddard, R. A., Gee, J. E., Wilkins, P. P, McCaustland, K. and Hoffmaster, A. R. 2009 Detection of pathogenic Leptospira spp. through TaqMan polymerase chain reaction targeting the LipL32 gene. Diagn. Microbiol. Infect. Dis. 64: 247255.

Subharat, S., Wilson, P.R., Heuer,C., CollinsEmerson, J. M. 2011. Evaluation of a SYTO9 real-time polymerase chain reaction assay to detect and identify pathogenic Leptospira species in kidney tissue and urine of New Zealand farmed deer. J. Vet. Diagn. Investig. 23(4):74352 .
Tansuphasiri, U., Chanthadee, R., Phulsuksombati, D. and Sangjun, N. 2006. Development of a duplexpolymerase chain reaction for rapid detection of pathogenic Leptospira. Southeast Asian J. Trop. Med. Public. Health. 37: 297-308.

Van Eys, G. J. J. M., Gravekamp, C., Gerritsen, M. J., Quint, W., Cornelissen, M. T. E., TerSchegget, J. and Terpstra, W. J. 1989. Detection of Leptospires in urine by polymerase chain reaction. J. Clinical Microbiol. 27(10): 2258-2262.

Vihol, Priti, D., Patel, J. M., Patel, J. H., Prasad, M. C., Dabas, V. S., Kalyani, I. H. and Tyagi, K.K. 2017. Seroepidemiology of Caprine Leptospirosis in South Gujarat Region of India. Int. J. Curr. Microbiol. App. Sci. 6(3): 1599-1608.

Vihol, Priti, D., Patel, J. M., Patel, J. H., Prasad, M. C., Kalyani, I. H. and Raval, J. K. 2016. Serological and clinicopathological studies on leptospirosis among sheep. $J$. Anim. Res. 6(4): 571-577.

Vijayachari, P., Sugunan, A. P., Umapathi, T. and Sehgal, S. C. 2001. Evaluation of dark ground microscopy as a rapid diagnostic procedure in leptospirosis. Indian J. Med. Res. 114: 54-58.

World Organization for Animal Health (Office International des Épizooties -OIE). 2013. Chapter 2.1.9 In: Manual of Diagnostic Tests and Vaccines for Terrestrial Animals. OIE, Paris, pp. 251-264.

Yang, C. W., Wu, M. S. and Pan, M. J. 2001. Leptospirosis renal disease. Nephrol. Dial. Transplant, 16:73-77.

\section{How to cite this article:}

Priti D. Vihol, Jatin H. Patel, Jignesh M. Patel, Vijendra S. Dabas, Irshadullakhan H. Kalyani, Chandrakant F. Chaudhari and Ashish C. Patel. 2017. Identification of Pathogenic Leptospira spp. Carrier Goats Using Polymerase Chain Reaction (PCR). Int.J.Curr.Microbiol.App.Sci. 6(12): 2174-2183. doi: https://doi.org/10.20546/ijcmas.2017.612.249 